\title{
Social Presence of Ruangguru in Social Media during Covid-19 Pandemic
}

\author{
Raihan Abiyan Fattah ${ }^{1}$, Firman Kurniawan Sujono ${ }^{1}$ \\ ${ }^{1}$ Magister of Communication Science, FISIP, Universitas Indonesia, Jl. Salemba Raya \\ No. 4, Jakarta 10430, Indonesia \\ *Corresponding author, e-mail: raihanabiyanf@gmail.com
}

\begin{abstract}
Covid-19 Pandemic gives many social changes in society specially in communications study. One important policy made during Covid-19 is related to students who are required to study at home. Ruangguru is top of mind in digital based learning company, especially during this pandemic. Covid-19 and this policy made Ruangguru as Indonesia online learning company with the most followers, to adapt in giving online communication message, especially in @ ruangguru (Instagram). This research aims to see the social presence of Ruangguru in social media (Instagram) during Covid-19 Pandemic through three dimensions of social presence, which are: social context, online communication, and interactivity. On previous research, it was mentioned that social presence relates to brand engagement. Brand's social presence in social media is important to be researched due to more brand using social media as primary communication tool to gain brand engagement. Method used in this research is case study with qualitative approach. Through Ruangguru's post on Instagram, researcher observes using three dimensions of social presence. The result of this research depicts Ruangguru as showing good social presence based on three dimensions of social presence during Covid-19 Pandemic in social media Instagram.
\end{abstract}

Keywords: Social Presence, Ruangguru, Social Media, Covid-19 Pandemic.

\section{Introduction}

President Joko Widodo on the March 2, 2020 issued official statement about existence of covid-19 transmission that infected two Depok, West Java, citizens and since then Indonesia admitted officially that crisis was happening. Various policies serve as countermeasures were issued, such as Physical Distancing, Work from Home, Study at Home, and Large Scale Social Restriction ('Pembatasan Sosial Berskala Besar' (PSBB)).

Those policies are conditions accelerated to force everyone to use digital network device. This acceleration is used to socialize, get information, fulfil primary needs, serve other people and perform various professional activities. This acceleration impacts education world with study at home policy. Incoming changes come so fast and are experienced by the society during Covid-19 Pandemic. Previously, learning was done directly in person, now it must be done at home with the help of digital media. This policy also makes formal education and many students adapt to the use of the digital medium, but not for online learning companies. As one of the non-formal education, online learning company which already applied learning through digital media is Ruangguru application.

Quoted from Ruangguru official website, Ruangguru is a company founded on 2014 and operates in non-formal education which focuses on education based service. Currently, Ruangguru has various technology based learning services, including virtual class service, learning videos subscription, online exams platform, private courses marketplace, and other educational contents which can be accessed through website and 
Ruangguru application. The mission of Ruangguru is to provide and extend access to good quality education through technology for all students, anytime and anywhere. In 2019, Ruangguru has cooperated with 32 out of 43 provincial government and more than 326 city government and has more than 10 millions users (elementary, junior high school and senior high school students) (Kartosapoetro, 2019).

Changes that happen in the society due to covid-19 surely affect online learning company, such as Ruangguru. In regard to learning at home, Ruangguru becomes one of the most popular applications with increment of daily active users (Masyrafina, 2020). It puts Ruangguru as top of mind in digital based learning company, especially during this pandemic. This achievement is due to communication role done by Ruangguru, especially through social media who have the largest followers as online learning company in Indonesia.

Under the platform bigger than social media, Social Networking Sites (SNS), such as Facebook, MySpace, LinkedIn, and Twitter has huge impact (Gironda \& Korgaonkar, 2014). Social media drastically changes our perspective of communication, this media helps the society to communicate freely despite of the geographic factor. Nowadays, communication mediated by this technology could be explained by Computer Mediated Communication (CMC) concept. The term CMC is used for any forms of communication done through a computer or other electronic devices (Kirk \& Sigrid, 2012).

Unlike analogue media, where mass media dictate and also shape public's preference, which in the end also produces mass culture, in the era of digital technology the role is played by media, such as Instagram, twitter, Facebook, YouTube and other various digital media (Kurniawan, 2020). This is related to web 2.0 development. This era of web 2.0 is a form of communication that comes from several factors, such as smartphone, mobile internet, and fused with social mobile application (Skinner, 2019).

Social media plays a dynamic role in developing and maintaining consumer-brand relationship, which gives a marketing potential in brand management (Moro \& Rita, 2018). Social media is used as a tool for organization to build relationship with public and provide various information and services to various public groups directly and indirectly (Joo \& Teng, 2016).

Members of social network website can be friends with each other in the network and they can also be a fan of a brand in fan page or the brand account (De Vries, Gensler, $\&$ Leeflang, 2012). The easiness in participating within social online community omits physical and temporal obstacle, increasing the probability of participation of consumer who might not be able to do it (Davis, Piven, \& Breazeale, 2014). Social media has intensified instant private interaction between brand and its community (Nambisan \& Watt, 2011). As one of the biggest online learning company, @ruangguru (Instagram account) has more than 900 thousand followers. Through social media, especially Instagram as Ruangguru's social media with the most followers, Ruangguru is involved in delivering the company's program which is adjusted with Covid-19 Pandemic.

The content of communication strategy of a company is influenced by the process of how it is shaped by different individuals inside the organization (Man, Abdullah, Tamam, \& Hasan, 2019). Ideally, content of the strategy starts with the evaluation in the entire organization about how the organization is seen by different stakeholders (reputation) according to vision and mission at a certain point of time. Once a company decided what product it will offer at what price, it also needs to determine how it will offer a place or promotion (Kotler, Kartajaya, \& Setiawan, 2017). Company has to be 
able to determine its product's distribution course with the purpose of ensuring its consumer.

Large scale social restriction regulation, especially how it requires teaching and learning activities to be done online, becomes a good moment for an online learning company, such as Ruangguru, to deliver the company's message via interactive content in social media. The purpose of this research is to understand how the social presence of Ruangguru in social media is perceived based on the content given to the public during Covid-19 Pandemic.

Traditional communication media, such as television, radio, magazine, and newspaper, have fulfilled the need of brands throughout generations. However, for these last few decades, there has been rising effort from brands to find a new media, something cheaper, organized, and potentially more effective than the existing media (Shimp \& Andrews, 2013). Currently, digital media is the most interesting platform to reach people out effectively. Digital media is used to deliver information and important message, such as news, training material, and information. Digital media is effective because it brings harmony and proximity to modern communication (Khan, 2009).

Informative online social content enables the users to evaluate the content that they are interested in to be involved in social interaction where it can be shown with social presence theory (Chang \& Hsu, 2016). Social presence theory highlights that the social presence of a media influences the receiver's (consumer) understanding of the content generated by the sender (media) (Chang \& Hsu, 2016).

Concept of social presence initially develops from the use of telecommunication and grows even more by adopting CMC and online technology in education (Cui, Lockee, $\&$ Meng, 2013). On the next research Osei-Frimpong and Mclean, they propose a framework that explains the integration of social presence, brand's involvement and moderation effect of content and commitment of a company (Osei-Frimpong \& McLean, 2018). In this research, it is important to know and to explain how a brand, particularly Ruangguru, shows social presence in social media Instagram related to Covid-19 issue.

Social presence was developed as independent subject in social psychology in 1970s (Cui et al., 2013). Currently the social presence concept is discussed widely in mediated communication context, but it is originally rooted in non-mediated interaction (Cui et al., 2013). In the beginning, it was developed by Short, Williams, and Christie (1976) to explain the effect of media telecommunication that can create communication (Lowenthal, 2009). They define social presence as level of interest between two communicators using communication media. Social presence shows relative significance of a relationship between two parties in interaction, and their argument also contributes to the development of media richness research and relational perspective in social presence field (Cui et al., 2013).

At first, social presence concept developed from the use of telecommunication and has been developing more with CMC adoption and online technology in education (Cui et al., 2013) which is also extended to social media research to explain the concept of social presence (Chang \& Hsu, 2016). According to Tu, social presence is level of feeling, perception, and reaction connected with CMC to other intellectual entities ( $\mathrm{Tu}, 2002)$. Social presence in social media is important, because when someone communicating through a medium feels having a distance with his/her communication pair and not feeling real, then the medium is considered as impersonal, cold and unfriendly (Hasanuddin, Pramudibyanto, \& Hermawati, 2012). 
In the end, social presence asses the quality of a medium in conveying social symptom. Therefore, the communicator can see its communication partner as real as multidimensional living creature (Hasanuddin et al., 2012). According to Tu and MsIsaac, there are three dimensions of social presence which can be used as theoretical framework in research, such as social context, online communication, and interactivity (Tu, 2002).

Social context is built based on characteristic of CMC user and their perception about CMC environment ( $\mathrm{Tu}, 2002$ ). It is also related to social impact of changes in society, including large area of population impact, community and organization setting, community in transition, individual and family impact, and infrastructure need of community. In the aspect of social marketing, social context is a belief, attitude, value, and application, which related to 'reality' of targeted group where social structure is related to obstacles and changes that happen (Cowan, 2006).

Online communication is a language used online and online language application, CMC attribute, computer literacy ability, online proximity, and online language ability (Tu, 2002). Terminologically, communication refers to the process of conveying a communicator, either with direct communication or using signs as communication symbol or helping tools to deliver the message through online media. Therefore, if it is to be examined further, online communication dimension relates to definition of medium quality as basic standard in determining social presence degree which can be seen from how communicator presents the message to the communication partner.

Interactivity includes the active communication and learning activities, in which CMC users engage, and the communication styles that they use ( $\mathrm{Tu}, 2002)$. In CMC, there are two kind of interactions, which are asynchronous (different time) and synchronous (real time). Response that happens in asynchronous CMC (different time) needs time to get response from other parties. In other words, interactivity is 'design' and strategy to stimulate social presence.

There has not been many research about social presence of a brand in Indonesia on social media, so through this research, researcher aims to give benefits to brand in showing social presence based on three dimension of social presence mentioned previously. Social presence theory is usually used to discuss online learning activity. Now, social presence is also used to discuss about the relationship of brand and consumer. Previous research of Osei-Frimpong and Mclean in 2018 said that there was a strong relation between social presence and brand engagement.

This research will study social presence dimension of Ruangguru in social media Instagram seen through symbolic interaction showed on Ruangguru's post. The essence of symbolic interaction is human activity, which is communication or meaningful exchange of symbol where symbolic interaction perspective try to understand human behaviour from the subject's point of view (Pranata, Latif, \& Fanani, 2019). The novelty on this research is it researches symbol on social media post using social presence dimension.

Type of post refers to content of the message has three categories called ICA (Information, Community and Action) (Lovejoy \& Saxton, 2012). First category, information, involves the spread of information related to the activity or organization of a brand. This category is one way where no dialogue interaction is expected from public to the brand or organization. Second category, community, expects dialogue from public to brand that aims to create a relationship and network to build a community. Last category, action, aims to make the public to do something for the organization. Actions 
that can be done are purchasing the product, using the service, visiting the website or other social media.

Table 1. Typology Post I-C-A (source: Lovejoy \& Saxton, 2012)

\begin{tabular}{cc}
\hline Typology & $\begin{array}{c}\text { Description } \\
\text { organization related to the interest of the organization. }\end{array}$ \\
\hline Community & $\begin{array}{c}\text { This category is two way, the function is to build dialogic relationship and to } \\
\text { create network with the public. There are two aspects in this category, which are } \\
\text { dialogue and community building (Saxton \& Waters, 2014). Dialogue aspect } \\
\text { aims to make direct conversation between the organization and the public. } \\
\text { Meanwhile, community building aspect aims to strengthen relationship } \\
\text { with the public. }\end{array}$ \\
Action $\quad \begin{array}{c}\text { Action category is a guidance for the public to do something for the organization } \\
\text { via promotional message and mobilization. This category is one way. For } \\
\text { example, invitation to come to an event, give donation, or to visit } \\
\text { specific website. }\end{array}$ \\
\hline Note: Type of post refers to content of the message has three categories called ICA \\
(Information, Community and Action)
\end{tabular}

\section{Methods}

Approach used in the research is qualitative approach. Qualitative research intends to understand its object, not to generalize but to make extrapolation of meaning behind the object (David \& Sutton, 2004). Method used in this research is case study. Case study is a method that investigates specific unique attached system (Baxter \& Babbie, 2004). In study case research, thorough investigation to a situation or occasion is done using systematic method to observe, gather data, analyze information, and report the result. The research uses descriptive approach that does not intend to look for relationship or to test a hypothesis. Descriptive research aims to give aspect or character description of a message or text (Eriyanto, 2011).

In this research, researcher uses primary data as @ ruangguru Instagram post which was uploaded related to Covid-19 Pandemic during February to April 2020. There are two observation methods, which are structured and non-structured. This research uses structured method, where structured method needs fewer data gathering since researcher only needs some data from the incident or interesting and relatable aspect that relates to the research subject being observed (Slack \& Rowley, 2001). To conclude, qualitative research is a research that aims to understand phenomena about what the research subject went through in terms of behaviors, perceptions, motivations, or holistic actions described by words and language (Moleong, 2017).

\section{Results}

This research uses Ruangguru's Instagram post as research object, in regards to this there are characteristics of message from post in social media. Lovejoy \& Saxton in 2012 did a development of typology post through a research in United States. After knowing kind of post in social media based on typology I-C-A Lovejoy and Saxton, researcher identifies several posts from @ ruangguru (Instagram account) according to the dimension of social presence from $\mathrm{Tu}$ and MsIsaac with structured method to show social presence of Ruangguru during Covid-19 Pandemic in social media Instagram.

First, social context, as mentioned before that this is influenced by changes that happen in the society. As messenger, @ ruangguru Instagram account adjust the content 
corresponding to the condition during Covid-19 Pandemic. In Figure 1, Ruangguru gives information to respond the covid-19 situation, they open free online school for students.
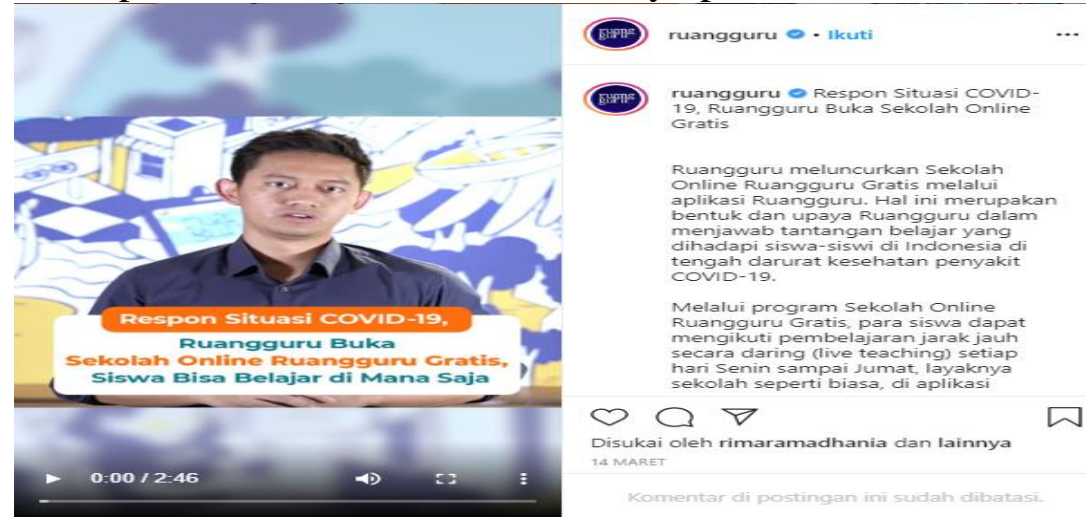

Figure 1. Posting of Ruangguru (Instagram) responding to Covid-19 situation (source: Instagram.com/ruangguru)

Kind of post in Figure 1 is information, it gives information about ruangguru's program corresponding to covid-19 which requires student to study at home. Ruangguru gives solution following the change that happens when learning method is accelerated from direct in person to indirect mediated by digital media. This program is accurately and quickly delivered through Instagram.

Social presence of Ruangguru is strengthened in social context with information and action kind of post consist of invitation to use ruangguru application and Telkomsel, Indosat, and XL phone number users can get free quota to access ruangguru application to support the free class program.
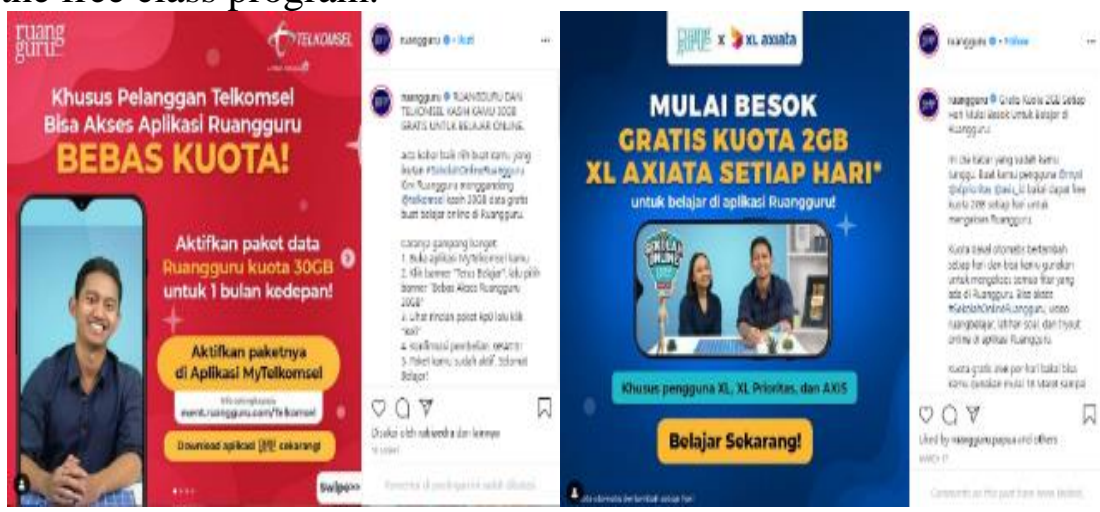

Figure 2. Posting of Ruangguru (Instagram) giving Information about Free Quota to access Ruangguru (source: Instagram.com/ruangguru)

Second is online communication, as mentioned previously other than the use of language and online language ability, this dimension is related to the quality of the medium used. There are two elements in Instagram post, which are photo or video and the caption used in the post. On social dimension, language utilization, especially in caption, is important because it can support the main message of the brand. The use of caption can be stronger if supporting social context related to the society, as mentioned before. 

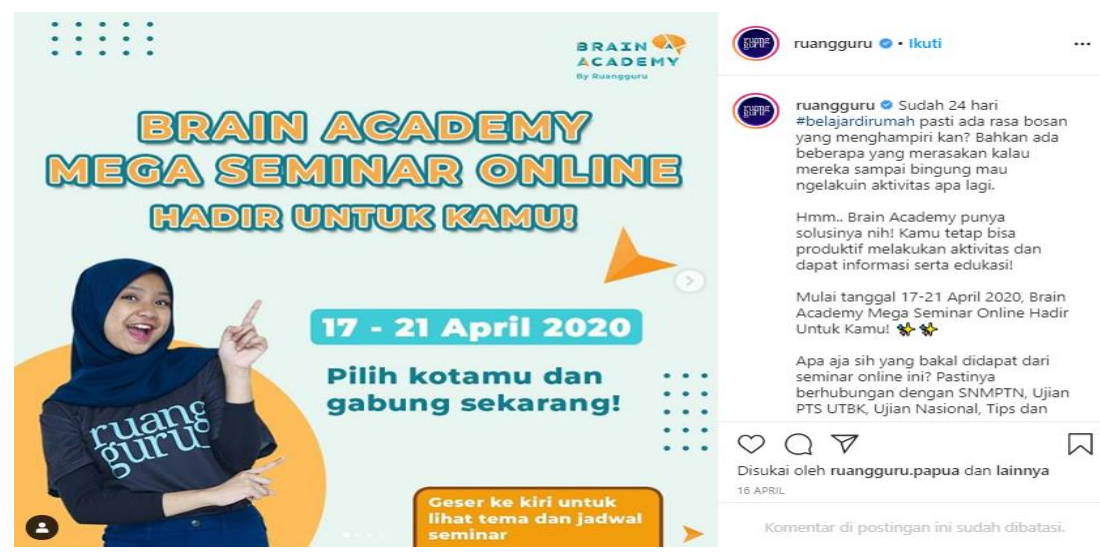

Figure 3. Posting of Ruangguru (Instagram) with Caption corresponding to Covid-19

Situation (source: Instagram.com/ruangguru)

The above post consists of information that Ruangguru will hold an online seminar entitled 'Brain Academy Mega Seminar Online.' Caption used on this post corresponds to Covid-19 situation where learning activity is done at home with caption: "It's been 24 days \#studyingathome you must be bored? Even some people feel they are confused about what to do anymore." This kind of post figure 3 accommodates all kind of post mentioned previously where it consists of information related to online seminar and also action to invite people to participate in the seminar. Through Instagram, public response can be seen through comments given on comment column of the post, considering there are many cities that cannot join the seminar. Not only through verbal, Ruangguru also uses visual communication, such as using public figure, for example, Nashwa with 1.9 million Instagram followers. Finally, online communication is built properly between Ruangguru and the public regarding the online seminar.

Third is interactivity, which is an active communication activity from communicator inviting the CMC public user to join in the communication being used. Ruangguru utilizes social media to increase social presence during Covid-19 Pandemic by giving mask as a bonus after subscribing Ruangguru. Afterwards, the followers who have mask are invited to create a challenge to take picture with the mask.
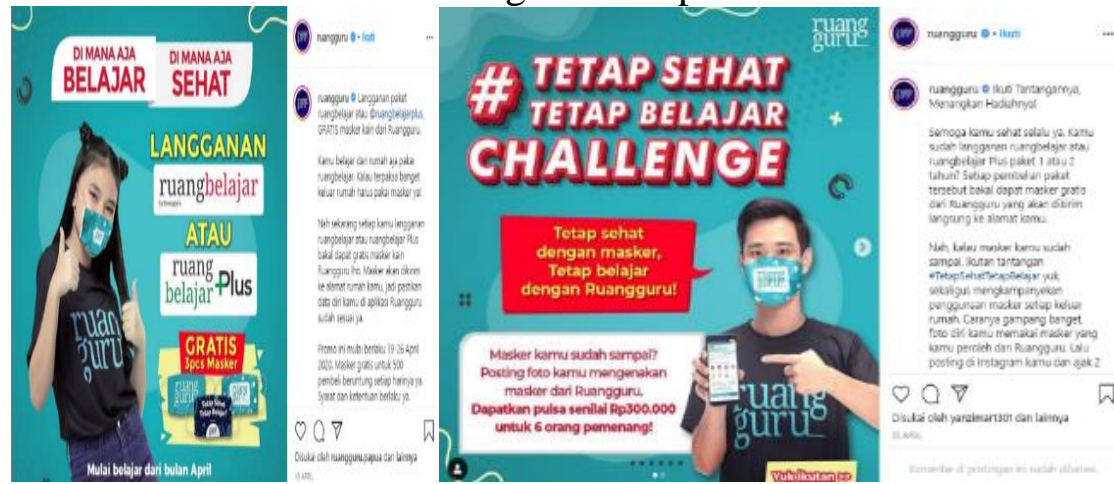

Figure 4. Posting of Ruangguru (Instagram) giving mask as Bonus and Invitation to create a challenge using a Mask (source: Instagram.com/ruangguru)

This kind of post is action, as one way invitation to the public to do something following the communicator's wish. It is used to stimulate social presence of Ruangguru corresponding to Covid-19. Action post is used as a trigger to build interactivity that supports social presence of Ruangguru brand. The invitation to post pictures done by 
ruangguru is expecting asynchronous (different time) response because people need to take pictures then post it on each own social media.

\section{Discussion}

Different social relationship shows positive and negative impact on the level of social presence. Covid-19 Pandemic gives multidimensional effect to people, from health, economy, and also education. Having collective problem especially in education, social presence of Ruangguru builds positive relationship because the information provided through information in the class and also free internet access by Ruangguru correspond to the social context currently being experienced by the people.

Although the conceptualization of social presence often focus to the perception of interlocutor, frequently this conceptualization extended to a bigger audience (Caspi \& Blau, 2008). It is difficult to explain explicitly the difference of personal and interpersonal or public communication through social media. The user of CMC needs to have communication ability that corresponds and relates to second dimension of social presence, which is online communication. With a strong social context in the previous explanation, social presence of Ruangguru becomes more visible, especially during Covid-19 Pandemic.

When we discuss about online communication, caption used here is also community kind where ruangguru builds dialogic relationship by corresponding the message delivered to the public. Relationship with the public is strengthened with the information delivery on figure 3 corresponds to the condition where people staying at home for 24 days due to large scale social restriction regulation and learning at home policy issued by the government.

Social media has several other characteristics, such as digitalization, interactive, asynchronous, and multimedia (Straubhaar, LaRose, \& Davenport, 2012). Combination of text, picture, and sound in two ways communication built in social media is the difference between new media and old media. Current social media, especially Instagram, becomes interactive platform for society to build communication. Instagram becomes a quite popular media and used actively by the society. According to Indonesia Landscape 2018 research done by We Are Social and Hootsuite, the amount of active Instagram users in Indonesia is 53 million users. In the end, message received by the society is not the same, the society can also determine when and what kind of message received by the society.

Two way exchange and freedom in exchanging content gives brand and consumer an opportunity to connect to each other (Helal, Ozuem, \& Lancaster, 2018). The creation of decentralization. The creation of decentralization of information where individual can be one of the sources of main information. This is called User-Generated Content or UGC, where the used to be passive media users (one way communication) become active (two ways communication) (Duffy, 2015). Customers now have control over the communication due to user-generated content cannot be completely controlled. Through the challenge, Ruangguru successfully created interactivity with positive invitation to use mask. Ruangguru's followers can share their enthusiasm towards the brand in their social media, united by their common interest related to Covid-19 Pandemic triggered by social presence of Ruangguru as we can see in figure 5. It is important to note that social presence shows that online social content is informative and it allows users to evaluate content that attracts them to involve in this social interaction (Chang \& Hsu, 2016). 


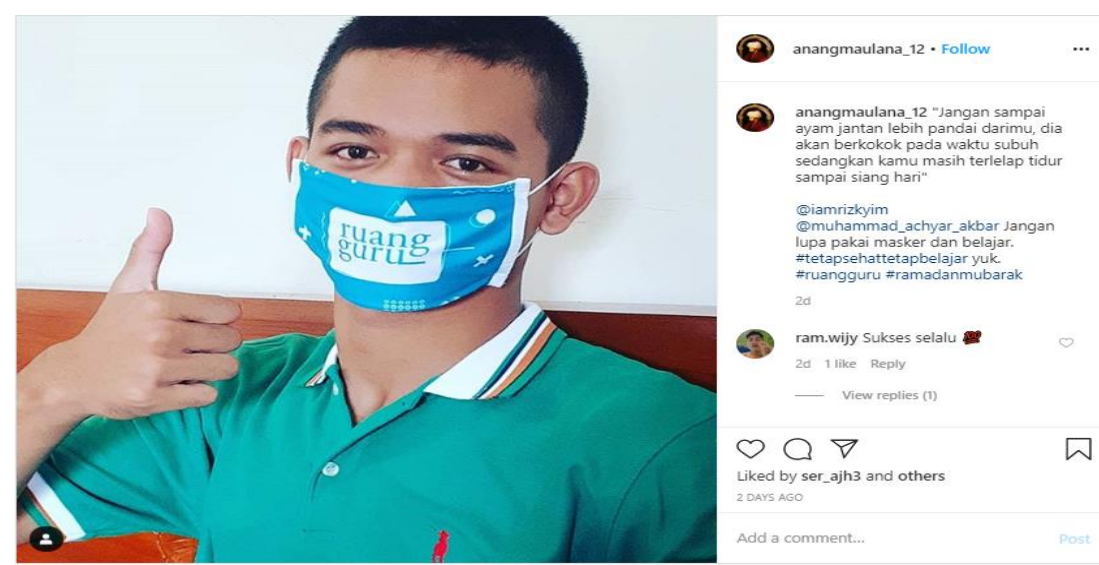

Figure 5. Posting of @ anangmaulana_12 (Instagram) joining the challenge from Ruangguru (source: Instagram.com/ruangguru)

As depicted in previous explanations through three kind of post in social media, which are information, community, and action; social presence of Ruangguru can be seen through three dimensions of social presence. The three dimensions in the end depict how social presence of Ruangguru can be seen during Covid-19 Pandemic to get trust from consumer. Consumer's trust is no longer vertical, where marketing campaign can easily influence consumer's psychology. In horizontal approach, where one consumer is seen as a part of various community, social factors, such as family, friendship, network in social media become the most determining factor in influencing consumer's perception of a brand.

Based on it we can see that consumer is always mentioned as having big influence. Moreover, these days consumer is no longer loyal to one particular brand. Once the experience element of brand involvement gone, in many cases, the emotional connection, that consumer has with the brand that gives them unique experience, will follow (Llopis, 2014). Consumer can no longer be seen as a collection of data that moves up and down from time to time and passive, but consumer is seen as a group of people with soul, emotion, and thoughts that interconnected. Brand that can build communication by implementing the three dimensions of social presence will get attention from consumer so the messages conveyed will be more effectively conveyed, especially during Covid-19 Pandemic period.

Along with the social restriction implementation, there is an increment on the use of digital media, especially in social media. Therefore, social presence is important for building brand engagement with consumer. Brand must understand and influence engagement, which will help brand to grow consumer's loyalty and will be impacted to business development. Ideal customer in digital era does not have to be a person who buys much (Chaffey \& Smith, 2017). Ideal customer can be influencer who can buy in small amount inconsistently, but can also give values and reviews which can be seen and influence other people. Engaged customers might be fanatic to the brand if they are keep being involved, thus creating motivation to do action to brand.

The limitation of this research is on the dynamism of social presence of Ruangguru during the pandemic that is not over yet. There are more social presence applications that can be done by ruangguru or other brands, considering the pandemic is not over yet. On the next research, research related to social presence can also be applied more deeply to the relation of brand and consumer, not only in the context of Covid-19 Pandemic issue. 


\section{Conclusion}

Social presence of Ruangguru in social media during covid-19 pandemic is elevated well through three dimensions, which are social context, social communication, and interactivity. Ruangguru can adapt to the change that happens in the society when it needs to accelerate learning online by adjusting the information and message that they give to the public through @ ruangguru Instagram account. In the end, social presence of Ruangguru is used competently to do program promotion that they have by adjusting the context during Covid-19 Pandemic. This research depicts how social presence of Ruangguru in social media is related to context of Covid-19 Pandemic. Researcher hopes that research about social presence can be developed in other social context along with the advancement of technology and communication medium that will continue to innovate in the future.

\section{Conflict of Interest}

The researchers certify that there is no conflict of interest with any financial, personal, or other relationships with other people or organization related to the material discussed in the manuscript.

\section{Acknowledgements}

The authors wants to give gratitude to @ ruangguru (Instagram) which has provided data for researchers to analyse, and thank to Ruangguru which optimally gives convenience in learning to students in Indonesia through its program. Gratitude is also given to all Indonesian citizens who fight against Covid-19.

\section{References}

Baxter, L. A., \& Babbie, E. (2004). The Basics of Communication Research. Belmont: Holly J. Allen.

Caspi, A., \& Blau, I. (2008). Social presence in online discussion groups: Testing three conceptions and their relations to perceived learning. Social Psychology of Education: An International Journal, 11(3), 323-346. https://doi.org/https://doi.org/10.1007/s11218-008-9054-2

Chaffey, D., \& Smith, P. (2017). Digital Marketing Excellence: Planning, Optimizing and Integrating Online Marketing (Fifth). New York: Routledge.

Chang, C.-M., \& Hsu, M.-H. (2016). Understanding the determinants of users' subjective wellbeing in social networking sites: an integration of social capital theory and social presence theory. Behaviour \& Information Technology 35. Journal of Brand Management, 10(9), 33-58.

Cowan, L. (2006). Understanding Social Context: Literature Review. https://doi.org/10.13140/RG.2.1.3035.4084

Cui, G., Lockee, B., \& Meng, C. (2013). Building modern online social presence: A review of social presence theory and its instructional design implications for future trends. Education and Information Technologies, 18(4), 661-685. https://doi.org/10.1007/s10639-012-9192-1

David, M., \& Sutton, C. D. (2004). Social Research: The Basics. London: SAGE.

Davis, R., Piven, I., \& Breazeale, M. (2014). Conceptualizing the brand in social media community: The five sources model. Journal of Retailing and Consumer Services, 21(4), 468-481. https://doi.org/10.1016/j.jretconser.2014.03.006 
De Vries, L., Gensler, S., \& Leeflang, P. S. H. (2012). Popularity of Brand Posts on Brand Fan Pages: An Investigation of the Effects of Social Media Marketing. Journal of Interactive Marketing, 26(2), 83-91. https://doi.org/10.1016/j.intmar.2012.01.003

Duffy, A. (2015). The road more travelled: How user-generated content can lead to homogenized travel journalism. Continuum, 29(6), 821-832. https://doi.org/10.1080/10304312.2015.1073686

Eriyanto. (2011). Analisis isi: Pengantar Metodologi untuk Penelitian Ilmu Komunikasi dan Ilmu-ilmu Sosial lainya. Indonesia: Prenada Media Group.

Gironda, J. T., \& Korgaonkar, P. K. (2014). Understanding consumers' social networking site usage. Journal of Marketing Management, 30(5-6), 571-605. https://doi.org/10.1080/0267257X.2013.851106

Hasanuddin, Pramudibyanto, H., \& Hermawati, Y. (2012). Kehadiran Sosial Dosen UT dalam CMC (Computer Mediated Communication) melalui Aktivitas Tutorial Online (Pengembangan Model Panduan Komunikasi bagi Tutor Tutorial Online UT). Lembaga Penelitian dan Pengabdian Kepada Masyarakat Universitas Terbuka.

Helal, G., Ozuem, W., \& Lancaster, G. (2018). Social media brand perceptions of millennials. International Journal of Retail and Distribution Management, 46(10), 977-998. https://doi.org/10.1108/IJRDM-03-2018-0066

Joo, T. M., \& Teng, C. E. (2016). use of Social Media in PR: A Change of Trend. World Academy of Science, Engineering and Technology International Journal of Humanities and Social Sciences, 10(4), 1279-1288.

Kartosapoetro, I. S. (2019). "RuangGuru" dan Perubahan Pendidikan di Indonesia. Retrieved July 7, 2020, from Detik.com website: https://news.detik.com/kolom/d4406697/ruangguru-dan-perubahan-pendidikan-di-indonesia

Khan, A. R. (2009). Digital Signage System (Royal Institute of Technology (KTH)). Retrieved from http://kth.divaportal.org/smash/get/diva2:510432/FULLTEXT01.pdf

Kirk, S. A., \& Sigrid, K. (2012). Computer-Mediated Communication Across Cultures: International Interactions in Online Environments. IGI Global.

Kotler, P., Kartajaya, H., \& Setiawan, I. (2017). Marketing 4.0 Moving from Traditional to Digital. New Jersey: John Wiley \& Sons, Inc.

Kurniawan, F. (2020). Digita Dilemma: Problem Kontemporer Adopsi Media Digital di Indonesia. Depok: Rajawali Pers.

Llopis, G. (2014). Consumers Are No Longger Brand Loyal. Retrieved November 3, 2019, from Forbes.com website: https://www.forbes.com/sites/glennllopis/2014/12/10/consumers-are-no-longerbrand-loyal/\#62d665892ae0

Lovejoy, K., \& Saxton, G. D. (2012). Information, Community, and Action: How Nonprofit Organizations Use Social Media. Journal of Computer-Mediated Communication, 17(3), 337-353. https://doi.org/10.1111/j.10836101.2012.01576.x

Lowenthal, P. R. (2009). The Evolution and Influence of Social Presence Theory on Online Learning. 124-139. https://doi.org/10.4018/9781605669847.ch010

Man, N. I., Abdullah, A. P. D. Z., Tamam, E., \& Hasan, N. A. (2019). A Communications Strategy of the Malaysian Research Universities to add Value. Jurnal The Messenger, 11(1), 56. https://doi.org/10.26623/themessenger.v11i1.1211 
Masyrafina, I. (2020). Karantina di Rumah, Pengguna Aplikasi Belajar Naik Drastis. Retrieved from Republika website: https://republika.co.id/berita/q81lwm380/karantina-di-rumah-pengguna-aplikasibelajar-naik-drastis

Moleong, L. J. (2017). Metodologi Penelitian Kualitatif(36th ed.). Bandung: PT. Remaja Rosdakarya Offset.

Moro, S., \& Rita, P. (2018). Brand strategies in social media in hospitality and tourism. International Journal of Contemporary Hospitality Management, 30(1), 343-364. https://doi.org/10.1108/IJCHM-07-2016-0340

Nambisan, P., \& Watt, J. H. (2011). Managing customer experiences in online product communities. Journal of Business Research, 64(8), 889-895. https://doi.org/10.1016/j.jbusres.2010.09.006

Osei-Frimpong, K., \& McLean, G. (2018). Examining online social brand engagement: A social presence theory perspective. Technological Forecasting and Social Change, 128(September 2017), 10-21. https://doi.org/10.1016/j.techfore.2017.10.010

Pranata, E. W., Latif, M. C., \& Fanani, F. (2019). Symbolic Interaction of The Deaf Students in Public School. Jurnal The Messenger, 11(1), 1. https://doi.org/10.26623/themessenger.v11i1.876

Saxton, G. D., \& Waters, R. D. (2014). What do Stakeholders Like on Facebook? Examining Public Reactions to Nonprofit Organizations' Informational, Promotional, and Community-Building Messages. Journal of Public Relations Research, 26(3), 280-299. https://doi.org/10.1080/1062726X.2014.908721

Shimp, T. A., \& Andrews, J. C. (2013). Advertising, Promotion, and other aspects of Integrated Marketing Communications. In Integrated Marketing communications (9 ed). Retrieved from https://scholarsbank.uoregon.edu/xmlui/bitstream/handle/1794/19082/Thesis Final-Bulka.pdf?sequence $=1$

Skinner, C. (2019). Manusia Digital (Terjemahan). Jakarta: PT Elex Media Komputindo.

Slack, F., \& Rowley, J. (2001). Observation: Perspectives on research methodologies for leisure managers. Management Research News, 24(1-2), 35-42. https://doi.org/10.1108/01409170110782496

Straubhaar, J., LaRose, R., \& Davenport, L. (2012). Media Now: Understanding Media, Culture and Technology (7th ed.). Wadsworth.

Tu, C. H. (2002). The impacts of text-based CMC on online social presence. Journal of Interactive Online Learning, 1(2), 1-24. 